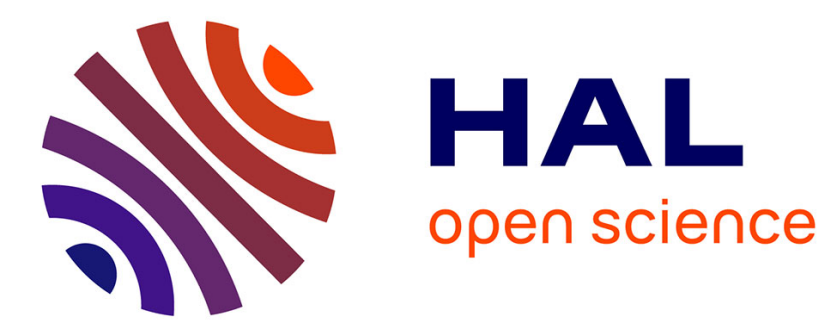

\title{
Methods of lipid-normalization for multi-tissue stable isotope analyses in tropical tuna
}

Fany Sardenne, Frédéric Ménard, Maxime Degroote, Edwin Fouché, Gaël Guillou, Benoit Lebreton, Stephanie J. Hollanda, Nathalie Bodin

\section{- To cite this version:}

Fany Sardenne, Frédéric Ménard, Maxime Degroote, Edwin Fouché, Gaël Guillou, et al.. Methods of lipid-normalization for multi-tissue stable isotope analyses in tropical tuna. Rapid Communications in Mass Spectrometry, 2015, 29 (13), pp.1253-1267. 10.1002/rcm.7215 . hal-01168999

\section{HAL Id: hal-01168999 \\ https://hal.science/hal-01168999}

Submitted on 26 Jun 2015

HAL is a multi-disciplinary open access archive for the deposit and dissemination of scientific research documents, whether they are published or not. The documents may come from teaching and research institutions in France or abroad, or from public or private research centers.
L'archive ouverte pluridisciplinaire HAL, est destinée au dépôt et à la diffusion de documents scientifiques de niveau recherche, publiés ou non, émanant des établissements d'enseignement et de recherche français ou étrangers, des laboratoires publics ou privés. 


\title{
Methods of lipid-normalization for multi-tissue stable isotope analyses in tropical tuna
}

Fany Sardenne ${ }^{1,2}$, Frédéric Ménard ${ }^{3}$, Maxime Degroote ${ }^{1}$, Edwin Fouché ${ }^{1,4}$, Gaël Guillou ${ }^{5}$, Benoit Lebreton $^{5}$, Stephanie Hollanda ${ }^{6}$, Nathalie Bodin ${ }^{2}$

$5{ }^{1}$ IRD, UMR MARine Biodiversity Exploitation and Conservation (MARBEC), Avenue Jean Monnet, Sète, FRANCE.

${ }^{2}$ IRD, UMR MARBEC, Fishing Port, Victoria, SEYCHELLES.

3 IRD, Mediterranean Institute of Oceanography (MIO), Aix-Marseille Université/CNRS/IRD/Université de Toulon, 13288 Marseille, FRANCE.

$10{ }^{4}$ INRA, UMR TOXALIM (Research Centre in Food Toxicology), Toulouse, FRANCE.

${ }^{5}$ CNRS-Université de la Rochelle, UMR Littoral Environnement et Sociétés (LIENSs), 2 rue Olympe de Gouges, F-17000 La Rochelle, FRANCE.

${ }^{6}$ Seychelles Fishing Authority (SFA), Fishing Port, Victoria, SEYCHELLES.

15 Key-words: Carbon, Nitrogen, C:N, lipid correction, large pelagic fish, trophic ecology.

\begin{abstract}
Rationale: The bias associated with lipid contents in fish tissues is a recalcitrant topic for trophic studies using stable isotopes. Lipids are depleted in heavy carbon isotope and lipid content varies

20 considerably among species, tissues and in both time and space. We applied and assessed here different correction methods for tropical tuna tissues.
\end{abstract}

Methods: We tested two types of normalization methods to deal with variable lipid content in liver, gonads, white and red muscles of yellowfin, bigeye and skipjack tuna: a chemical extraction using dichloromethane and a mathematical correction based on three modeling approaches (linear, non-

25 linear and mass balance models). We measured isotopic values of bulk and lipid-free tissues and assessed the predictive ability of the correction models with the lipid-free measurements. Models' parameters were estimated from our dataset and stemmed from published studies on other species.

Results: Comparison between bulk, lipid-free and lipid-corrected isotopic values demonstrated that (1) chemical extraction using dichloromethane did not affect $\delta^{15} \mathrm{~N}$ values; (2) change in $\delta^{13} \mathrm{C}$ values

30 after extraction was tissue-specific; (3) lipid-normalization models using published parameters' estimates failed to predict lipid-corrected $\delta^{13} \mathrm{C}$ values ; (4) linear and non linear models using parameters estimated for each tissue from our dataset provided accurate $\delta^{13} \mathrm{C}$ predictions for all tissue, and mass balance model for white muscle only.

Conclusion: Models using published parameters' estimates from extra species cannot be used. 
35 According to a range of lipid content that do not exceed $45 \%$, we recommend the linear model to correct bulk $\delta^{13} \mathrm{C}$ values in the investigated tissues but parameters have to be estimated from a proportion of the original data for which chemical extraction is required and isotopic values of bulk and lipid-free tissues are measured. 


\section{INTRODUCTION}

40 Stable isotope analysis (SIA) is a widespread tool in trophic ecology, frequently used to understand how marine food webs are structured and how marine ecosystems function ${ }^{[1]}$. The isotopic approach is based on a predictable relationship between a consumer and its preys, i.e. a stepwise enrichment in heavier isotope. With a low enrichment factor between trophic levels, carbon isotope ratios $\left({ }^{13} \mathrm{C} /{ }^{12} \mathrm{C}\right.$, expressed as $\left.\delta^{13} \mathrm{C}\right)$ allow for discriminating different sources of primary production (e.g. 45 nearshore vs. offshore systems, or benthic vs. pelagic systems) while nitrogen ratios $\left({ }^{15} \mathrm{~N} /{ }^{14} \mathrm{~N}\right.$, expressed as $\delta^{15} \mathrm{~N}$ ) provide an index of animal's trophic position due to preferential retention of ${ }^{15} \mathrm{~N}$ during metabolism and excretion, and consequently a higher enrichment in $\delta^{15} \mathrm{~N}$ value between diet and consumer. Although the use of SIA has greatly improved the understanding of predator-prey interactions and trophic dynamics in marine environment, some limitations have also been pointed

50 out because of ecosystem complexity, and variation in isotopic fractionation as well as tissue growth and isotopic turnover (e.g., ${ }^{[2-7]}$ ).

For the sake of standardization and of result comparability, trophic studies on fish using stable isotopes are recommended to be conducted on one particular tissue, usually white muscle due to its relative biochemical homogeneity and stability ${ }^{[8]}$. In contrast, species-specific studies such as diet

55 shift experiments have highlighted the strong need and interest to work on multiple tissues with different turnover rates ${ }^{[9-13]}$. Beyond different turnover rates, tissue-specific isotopic signatures are also attributed to their biochemical composition, i.e., lipid and protein contents and their constituents fatty acids and amino acids ${ }^{[14,15]}$. The tissue-specific allocation of these dietary components with different isotopic signatures largely influences the tissues' isotopic signatures (i.e.,

60 "isotopic routing",[16,17]).

Lipids are depleted in ${ }^{13} \mathrm{C}$ relative to protein and glycogen due to the different biochemical pathways involved in their respective synthesis ${ }^{[18]}$. Indeed the $\delta^{13} \mathrm{C}$ value measured in a sample does not only reflect the diet of the individual, but is also related to the lipid composition of the tissue sample, which is known to vary considerably among tissues, individuals and species. Two different

65 methods have been proposed to account for lipid influence on $\delta^{13} \mathrm{C}$ value: either chemical extraction prior to SIA or mathematical correction of the bulk tissue values. The former successfully removes lipids from tissue samples and gives lipid-free $\delta^{13} \mathrm{C}$ values. However, some chemical extraction method can affect $\delta^{15} \mathrm{~N}$ by removing some protein compounds linked to lipids (e.g., lipoproteins or transmembrane proteins). Two separate analyses for carbon and nitrogen stable isotopes is then

70 required $^{[8,19-21]}$, while some methods allow for simultaneous carbon and nitrogen SIA by using specific solvent mixtures; but they remain expensive and time consuming ${ }^{[22-24]}$. The latter consists in mathematical models that predict lipid-corrected isotope values using SIA of bulk tissue and different covariates including a proxy of lipid content. Two main types of mathematical corrections 
80 In this paper, we dealt with the bias associated with variable lipid content in several tissues of three tuna species: bigeye tuna (Thunnus obesus; BET), skipjack tuna (Katsuwonus pelamis; SKJ) and yellowfin tuna (T. albacares; YFT). These large predatory fishes are widely exploited by industrial fisheries and their ecological role in trophic functioning of open ocean ecosystems still needs to be improved. During the last decade, several authors have applied SIA on the white muscle of tuna to 85 investigate their trophic ecology ${ }^{[34,46-49]}$. However, due to the high mobility of these large pelagic species and their opportunistic behavior (i.e., non-selective predation constrained by local prey availability and predator-prey size ratios ${ }^{[50]}$ ), interpretation of isotopic data is not obvious. In parallel, multi-tissue analyses were developed in trophic studies of bluefin and yellowfin tuna to refine results about diet shifts ${ }^{[13,46]}$ but the issue of the influence of lipids on the tissue-specific

90 isotopic signature has not been investigated in tropical tuna yet.

The central objective of this study was to deal with the highly variable lipid content in tuna tissues that impacts carbon isotopic values and interpretation, and then to assess the reliability of lipid removal using chemical extraction versus mathematical corrections that predict lipid-corrected $\delta^{13} \mathrm{C}$ values. We therefore measured isotopic values of bulk and lipid-free white muscle, red muscle, liver

95 and gonad tissues of SKJ, YFT and BET tuna caught in the Western Indian Ocean. We applied three types of mathematical corrections to the bulk measurements, with parameters either estimated from our data or selected in related studies, and assessed the predictive ability of the correction models with the lipid-free measurements. Then we discussed the relevance of mathematical normalization versus lipid removal. Finally, bulk and lipid-free isotopic signatures were discussed

100 in terms of tissue-specific biochemical composition.

\section{MATERIAL AND METHOD}

\section{Fish and tissue collection}

A multi-species sampling was carried out from June 2012 to January 2014 during the unloading of

105 the purse seiners at Victoria port (Seychelles) and was based on a 2-step methodology: (i) the ship wells were selected from among those containing fish from one set only, to obtain the exact fishing date and position, and (ii) fish from the three species of interest were chosen to sample the size range of purse-seine catches and to collect different life stages (i.e., immature and mature fish). A 
total of 39 BET, 42 SKJ and 48 YFT were collected throughout the Western Indian Ocean, and 110 processed at the laboratory. First, the total fish weight $\left(\mathrm{W}_{\mathrm{T}}, \mathrm{kg}\right)$, the fork length $\left(\mathrm{F}_{\mathrm{L}}, \mathrm{cm}\right)$, which refers to the length from the tip of the snout to the fork of the tail, and the sex were recorded for each individual. The weights of gonads and viscera (including stomach, liver, intestine, pyloric caecum, kidney, heart and spleen) were also determined and allowed for the estimation of the fish somatic weight ( $\mathrm{W}_{\mathrm{S}}$ : total fish weight minus viscera and gonad weights) and the gonadosomatic

115 index (GSI: ratio between the gonad and somatic weights). Then, two samples of around $2 \mathrm{~g}$ on a wet weight (ww) basis were taken from the dorsal white muscle (W; under the dorsal spine on the left side), red muscle (R; under the pectoral tail on the left side), liver (L) of each fish, as well as from gonads $(\mathrm{G})$ for mature ones. All samples were stored at $-80^{\circ} \mathrm{C}$ until further analyses.

\section{Carbon and nitrogen stable isotope analysis}

A total of 468 samples (129 L, $128 \mathrm{R}, 129 \mathrm{~W}$ and $82 \mathrm{G}$ ) were freeze-dried to preserve the integrity of the tissues ${ }^{[51]}$. Each dried sample was then ground up to a fine homogeneous powder with a mixer mill MM200 (Retsch, Eragny sur Oise, France), and split into two sub-samples: the first one was kept bulk in a dry room until encapsulation, while the second one was treated for lipid

125 extraction.

\section{Lipid extraction method}

Lipids were extracted according to the method of Bodin et al. ${ }^{[24]}$. Briefly, approximately $350 \pm 100 \mathrm{mg}$ of each powdered and dried sample was weighed and extracted with $8 \mathrm{~mL}$ of 130 dichloromethane $\left(\mathrm{CH}_{2} \mathrm{Cl}_{2}\right)$ at $100^{\circ} \mathrm{C}$ under 1900psi for 10 minutes using a Dionex ASE 200 Accelerated Solvent Extractor (Voisins De Bretonneux, France). The lipid-free samples were dried under an extractor fan and stored in a dry room until encapsulation. The extracts were evaporated to dryness using a N-Evap 111 extractor (OA-SYS, Berlin, USA) at a bath temperature of $35^{\circ} \mathrm{C}$ and residues were weighed on an Adventurer Pro (OHAUS, Nänikon, Swiss) analytical balance to the

135 nearest $0.1 \mathrm{mg}$ to determine the total lipid content of the samples expressed in $\%$ of dry weight (dw).

\section{Isotope Ratio Mass Spectrometry}

We weighed $0.4 \pm 0.1 \mathrm{mg}$ of each dried sample on a XP6 Metler Toledo microbalance (Viroflay, France) to the nearest $\mu \mathrm{g}$ and packed into $8 \times 5 \mathrm{~mm}^{2}$ pressed tin capsules (Sylab, Metz, France) for

140 simultaneous C and N SIA. Samples were analyzed using an Elemental Analyser (Flash EA 1112, Thermo Scientific, Milan, Italy) coupled to an Isotope Ratio Mass Spectrometer (Delta V Advantage with a Conflo iV interface, Thermo Scientific, Bremen, Germany) (EA-IRMS) at the LIENSs stable isotope facility (La Rochelle, France). Results were reported in the $\delta$ unit notation 
and expressed as per mil (\%o) relatively to international standards (Vienna-Pee Dee Belemnite for

145 carbon and atmospheric $\mathrm{N}_{2}$ for nitrogen). Calibration was done using reference materials (USGS24, IAEA-CHE, -600 for carbon; IAEA-N2, -NO-3, -600 for nitrogen). Analytical precision based on replicate measurements of internal laboratory standard (acetanilide, Thermo Scientific) was < $0.15 \%$ for both $\delta^{15} \mathrm{~N}$ and $\delta^{13} \mathrm{C}$. C: $\mathrm{N}$ ratios were determined from $\%$ element weight.

The extent of chemical extraction for lipid-free sub-samples was checked through the C:N ratio: 38

$150 \mathrm{~L}$ and two $\mathrm{G}$ samples showed C:N ratios $>4$ and were considered still fatty ${ }^{[25]}$. These 40 samples were submitted to a second ASE extraction and EA-IRMS analysis as described above to prevent for any possible leftover lipids. The final $\mathrm{C}: \mathrm{N}$ ratios, $\delta^{13} \mathrm{C}$ and $\delta^{15} \mathrm{~N}$ values obtained were considered as lipid-free results. The total lipid content of these 40 samples corresponds to the sum of the masses of the two extracted materials.

\section{Lipid class and protein analyses}

A total of 219 samples $(61 \mathrm{~L}, 63 \mathrm{R}, 62 \mathrm{~W}$ and $33 \mathrm{G})$ were submitted to additional analyses to determine the tissue biochemical composition of the three tuna species. Approximately $250 \pm 50 \mathrm{mg}$ of each wet sample were weighed on an analytical balance to the nearest $\mathrm{mg}$, then crushed using a

160 FastPrep System ${ }^{\circledR}$ (MP Biomedicals, Illkirch, France) and extracted with $2 \mathrm{~mL}$ of dichloromethane:methanol (2:1, v/v) (Sigma-Aldrich, St. Quentin Fallavier, France). After centrifugation the lower layer was collected then evaporated and re-suspended in a known volume of dichloromethane. An aliquot of the extract was spotted on chromarods SIII (rods of quartz covered with silica), and separated into lipid classes and quantified using an Iatroscan MK-6s

165 (Mitsubishi Chemical Medience, Tokyo, Japan) thin-layer chromatography-flame ionization detector analyzer (TLC-FID) ${ }^{[52]}$. Concentrations of triacylglycerols (TAG) and phospholipids (PL), the two main lipid classes in tropical tuna representative of reserve and structure lipids respectively ${ }^{[53]}$, were expressed in $\%$ wet weight (ww) using suitable calibration curves.

The total protein content was determined using bicinchoninic acid protein assay kit (BCA, Sigma-

170 Aldrich, St. Quentin Fallavier, France). Approximately $15 \pm 5 \mathrm{mg}$ of each wet sample were weighed to the nearest mg, incubated with BCA after grinding in mixer mill MM400 (Retsch, Eragny sur Oise, France) and submitted to successive heat shocks (i.e., two passages of 30 seconds in liquid nitrogen and 5 minutes in ultrasonic baths at $30^{\circ} \mathrm{C}$ performed alternately). Absorbance at $520 \mathrm{~nm}$ was determined using Infinite 200 spectrophotometer (TECAN, Lyon, France) and converted in

175 protein concentration using Bovine Serum Albumine (BSA) as reference. Total protein contents were expressed in \% ww.

\section{Statistical analyses and models}


Non parametric statistics (Wilcoxon's rank test and Spearman's rank correlation) were applied to 180 our dataset.

General effects of lipid on SIA. The effect of lipid extraction on $\delta^{15} \mathrm{~N}$ and $\delta^{13} \mathrm{C}$ values was tested using paired Wilcoxon's tests (with $V$ the Wilcoxon's statistic). The potential effect of explanatory variables (tissue, species, sex or lipid content) on differences between bulk and lipid-free $\delta^{13} \mathrm{C}$ and then $\delta^{15} \mathrm{~N}$ values was assessed using linear regressions and Box-Cox transformations for variance 185 stabilization. Indeed our sample size was large enough to consider that non-normality of residuals should not adversely affect the inferential procedures. Mean values were expressed $\pm 1 \mathrm{SD}$. The coefficient of variation ( $\mathrm{CV}$ in \%) was used for comparing range of variation. Hereafter the notations are: $\Delta \delta^{15} \mathrm{~N}=\delta^{15} \mathrm{~N}_{\text {lipid-free }}-\delta^{15} \mathrm{~N}_{\text {bulk }}$ and $\Delta \delta^{13} \mathrm{C}=\delta^{13} \mathrm{C}_{\text {lipid-free }}-\delta^{13} \mathrm{C}_{\text {bulk }}$.

Lipid-normalization modeling. Equations of lipid normalization models used $\mathrm{C}: \mathrm{N}_{\text {bulk }}$, lipid content 190 and $\delta^{13} \mathrm{C}_{\text {bulk }}$ to predict a lipid-corrected $\delta^{13} \mathrm{C}$ value $\left(\delta^{13} \mathrm{C}_{\text {corr }}\right)$. Our data confirmed that bulk C:N ratio $\left(\mathrm{C}: \mathrm{N}_{\text {bulk }}\right)$ was a reliable proxy of lipid content (for all tissues, Figure 1). Here we tested three models that include all types of lipid normalization models (Table 1): the non-linear model of McConnaughey and McRoy ${ }^{[25]}$ [eq1], the linear model of Post et al. ${ }^{[32]}$ [eq2], and the mass balance equation of Fry ${ }^{[27]}$ [eq3]:

$$
\begin{aligned}
& \text { [eq1] } \delta^{13} C_{\text {corr }}=\delta^{13} C_{\text {bulk }}+D \times\left(-0.207+\frac{3.9}{1+287 / L}\right) \\
& \text { [eq2] } \delta^{13} C_{\text {corr }}=\delta^{13} C_{\text {bulk }}+a \times C: N_{\text {bulk }}+b \\
& \text { [eq3] } \delta^{13} C_{\text {corr }}=\delta^{13} C_{\text {bulk }}+D-\left(\frac{D \times C: N_{\text {pureproteins }}}{C: N_{\text {bulk }}}\right)
\end{aligned}
$$

Parameters are defined in Table 1. Models were first implemented using parameters based on our dataset. In [eq1] $L$ was the lipid content from the ASE extraction of each sample, and in [eq3] the mean $\mathrm{C}: \mathrm{N}_{\text {lipid-free }}$ for each tuna tissue was used as the $\mathrm{C}: \mathrm{N}$ of pure proteins. Parameters $a$ and $b$ in [eq2], the lipid-protein discrimination $D$ in [eq1] and [eq2] were estimated from our dataset and for each tissue using least-squares estimation.

Then models were implemented using parameters based on published studies. In [eq1] and [eq3] we used a value of $7.49 \%$ for $D$ in muscles and $8 \%$ for liver and gonads based on Logan et al. investigations on bluefin tuna ${ }^{[35]}$. $I$ was fixed to -0.207 in [eq1] as in McConnaughey and McRoy ${ }^{[25]}$ and we adopted for $a$ and $b$ in [eq2] the value proposed by Post et al. ${ }^{[32]}$ for aquatic animals $(0.99$ and -3.32 , respectively). To assess predictive performances, we trained each model with a random subset of the data (i.e., 2/3 of the data in each tissue). A cross validation was performed using the parameters estimated from the training data, in order to predict the unused data (validation dataset). 
210 Besides we predicted six sets of lipid-corrected $\delta^{13} \mathrm{C}$ data using models [eq1], [eq2] and [eq3] in both parameters' configuration. To assess the quality of each model, predicted values were compared to the observed data from the validation dataset, and differences were tested using paired Wilcoxon's test. Differences between the lipid-corrected and observed lipid-free $\delta^{13} \mathrm{C}$ values are noted as $\Delta \delta^{13} \mathrm{C}_{\text {error }}$ with $\Delta \delta^{13} \mathrm{C}_{\text {error }}=\delta^{13} \mathrm{C}_{\text {corr }}-\delta^{13} \mathrm{C}_{\text {lipid-free. }}$ The process of cross-validation on

215 random subsets was repeated 500 times. Thereby paired Wilcoxon's tests were carried out for each model and at each trial, and means, maxima and distributions of $\Delta \delta^{13} \mathrm{C}_{\text {error }}$ were computed or plotted to detect any mismatch.

Lipid class composition and total protein content. The effects of tissue and sex on lipid class concentrations and total protein content were tested for each tuna species using Wilcoxon's test.

220 Ranges of variation were compared using CV.

Statistical analyses were performed using R 3.0.2 software ${ }^{[54]}$. Function $n l s$ of library MASS was used for nonlinear least-squares estimates.

\section{RESULTS}

225 Morphological characteristics $\left(\mathrm{F}_{\mathrm{L}}\right.$ and $\left.\mathrm{W}_{\mathrm{T}}\right)$ of the sampled tuna as well as their tissue isotopic composition and total lipid content are presented in Table 2.

\section{Bulk tissue characteristics}

Lipid and protein composition. The total lipid and the protein contents varied among tissues and

230 species. Liver was on average the fattest and white muscle the leanest somatic tissue for all species and lipid content was similar in red muscle and in gonads $(V=5600, p=0.41)$. SKJ showed the lowest lipid variation in liver $(\mathrm{CV}=36.3 \%$, min-max $=8.1-30.4 \% \mathrm{dw})$ and in white muscle $(25.4 \%$, $1.08-3.6 \% \mathrm{dw})$. For YFT, CV was $57 \%$ in liver $(2.7-43.3 \% \mathrm{dw})$ and $45.8 \%$ in white muscle $(0.3-$ $5.7 \% \mathrm{dw})$. For BET, CV was $49 \%$ in liver $(6.6-40 \% \mathrm{dw})$ and $65 \%$ in white muscle $(1.2-8.8 \% \mathrm{dw})$.

235 Red muscle showed the largest lipid variation in BET (45.2\%, 3.1-26.2\% dw) compared to YFT $(30.4 \%, 5.5-19.3 \% \mathrm{dw})$ and SKJ $(29.6 \%, 4.4-18.1 \% \mathrm{dw})$. Gonads of SKJ had a smaller range of variation in lipid content (21.2\%) compared to BET (63.4\%) and YFT (60.6\%). In addition, GSI of mature tuna was correlated with the lipid content of gonads (Spearman's statistic $S=56408$, $p<0.001$ ) only (liver: $S=117758, p=0.15$; red muscle: $S=150494, p=0.24$; white muscle: $S$

$240=144226, p=0.69)$. For all species, liver had higher protein levels than white muscle $(V=2813$, $p<0.01)$ and red muscle $(V=5289, p<0.001)$. Finally, very few reserve (TAG) lipids were recovered in white muscle of the three species (Figure 2), while red muscle and liver, which had higher contents than white muscle (liver: $V=3646.5, p<0.001$ and red muscle: $V=4020, p<0.001$ ), did not 
differ significantly $(V=2403, p=0.76)$. Structural lipids (PL) were higher in red muscle than in liver $245(V=3259, p<0.01)$, and higher in liver than in white muscle $(V=3668, p<0.001)$. TAG and proteins contents in gonad of the three species were higher in female than in male $(V=236, p<0.01$ and $V=319, p<0.01$, respectively) but differences were not significant for PL ( $V=135, p=0.77$ ).

$\delta^{15} N$, $\delta^{13} C$ values and $C: N$ ratios. Bulk $\delta^{15} \mathrm{~N}$ and $\delta^{13} \mathrm{C}$ values varied between tissue and species.

250 Mean bulk $\delta^{15} \mathrm{~N}$ values ranked BET $>$ YFT $>$ SKJ in all tissues. Liver (9\%), white muscle (8.9\%), gonads $(8.5 \%)$ and red muscle $(7.8 \%)$ had very close $\mathrm{CV}$ of bulk $\delta^{15} \mathrm{~N}$ values, and, overall, YFT exhibited the greatest $\mathrm{CV}$ and BET the lowest. White and red muscles had low $\mathrm{CV}$ of bulk $\delta^{13} \mathrm{C}$ values (2.4 and 2.7\%, respectively), while liver and gonads showed higher but similar CV (4.5 and $4.7 \%$, respectively). Finally, bulk C:N ratios varied according to lipid content variation: $21.6 \%$ in

255 liver, $13.4 \%$ in gonads, $7.4 \%$ in red muscle and only $2.2 \%$ in the leanest tissue, the white muscle. Interestingly, bulk $\mathrm{C}: \mathrm{N}$ ratios significantly differed between male and female in SKJ gonads only $(V=236, p<0.001)$, with higher values in females (mean $\mathrm{C}: \mathrm{N}>4)$.

\section{Influence of lipid extraction on tissue isotopic composition}

260 Effect of ASE extraction method. Most of the samples showed a C:N ratio $<4$ after a first lipid extraction, except for 40 tissues characterized by higher total lipid contents $(18.5 \pm 7.7 \% \mathrm{dw})$. A second extraction was then processed, which removed on average $2 \% \mathrm{dw}$ more of lipids (between 0.5 and $10 \%)$. The repeated extraction did not significantly affect $\delta^{15} \mathrm{~N}$ values ( $\left.V=481, p=0.21\right)$, but it slightly increased $\delta^{13} \mathrm{C}$ values $(0.1 \%$ in mean, $V=585, p<0.05)$ and surprisingly the $\mathrm{C}: \mathrm{N}$ ratio

265 (0.08 in mean, $V=67, \mathrm{p}<0.001$ ) (Table 3). Despite the two chemical extractions performed successively, 19 samples were still characterized by C:N ratio $>4$.

$\delta^{15} \boldsymbol{N}$ and $\delta^{13} \boldsymbol{C}$ changes after lipid extraction. A tiny but significant increase of $\delta^{15} \mathrm{~N}$ was observed after lipid extraction $\left(\Delta \delta^{15} \mathrm{~N}=0.1 \pm 0.2 \%\right.$; $\left.V=85992, p<0.001\right)$. A tissue effect was detected at the

$2705 \%$ significance level by the regression linear applied to $\Delta \delta^{15} \mathrm{~N}$ values (Table 4). Obviously $\delta^{13} \mathrm{C}$ values increased strongly after lipid extraction $(V=108567, p<0.001)$. Linear regression results showed that lipid content, tissue and sex affected $\Delta \delta^{13} \mathrm{C}$ values (Table 4). The highest change in $\delta^{13} \mathrm{C}$ value was observed in liver $\left(\Delta \delta^{13} \mathrm{C}=1.6 \pm 0.4 \%\right)$ and the lowest in white muscle $\left(\Delta \delta^{13} \mathrm{C}=\right.$ $0.1 \pm 0.1 \%$ ). The variability of the $\delta^{13} \mathrm{C}$ values was clearly reduced in all tissues after the lipid 275 extraction: CV decreased from 4.8 to $3.6 \%$ in gonads, from 4.5 to $2.5 \%$ in liver and from 2.7 and $2.4 \%$ to 2.3 and $2.1 \%$ in red and white muscles, respectively. Gonads were the only tissue with differences between male and female: $\mathrm{C}: \mathrm{N}_{\text {lipid-free }}$ ratios measured in gonads were positively correlated to GSI in females for the three species (BET: $V=144, p<0.001$; SKJ: $V=186, p<0.01$ and 
YFT: $V=121, p<0.001$ ) and negatively in males (BET: $V=81, p<0.001$; SKJ: $V=188, p<0.05$ and

280 YFT: $V=361, p<0.001)$ (Figure 3). Finally C: $\mathrm{N}_{\text {lipid-free }}$ ratios were less variable in muscles $(\mathrm{CV}=1.3$ and $3.7 \%$ in white and red muscles, respectively) than in liver and gonads (9.6 and 9.2\%, respectively).

\section{Lipid correction models for $\delta^{13} \mathrm{C}$ values}

As tissue impacted lipid content and bulk C:N ratios, models were fitted for each tissue. Indeed our

285 results did not justify species- or sex-specific models.

We then assessed the predictive performance of the three models in the two parameters' configuration: based on our dataset and based on published studies. Table 5 presents the estimated values of parameters for each tissue and from our dataset, and Table 6 displays the results of the cross validation procedure that was repeated 500 times. Results of the paired Wilcoxon's tests between predicted and observed values were expressed in $\%$ of acceptable $p$-values (i.e., $\%$ of $p$ $>0.05$ ) among the 500 iterations. The three models [eq1], [eq2] and [eq3] using parameters based on published studies gave very bad predictions with systematic discrepancies with $\delta^{13} \mathrm{C}_{\text {lipid-free. Figure } 4}$ displays the distribution of $\Delta \delta^{13} \mathrm{C}_{\text {error }}$ values computed from the three models using parameters from our dataset. For white muscle, the three models provided reliable predictions and were suitable for 295 correcting bulk $\delta^{13} \mathrm{C}$ values. Again [eq1] and [eq2] gave accurate predictions for the three other tissues even if maximum differences between $\delta^{13} \mathrm{C}_{\text {corr }}$ and $\delta^{13} \mathrm{C}_{\text {lipid-free }}$ could occasionally be much greater than 1\%. However [eq3] did not provide the same level of good predictions compared to the other models: systematic mismatch was observed in the distribution of the $\Delta \delta^{13} \mathrm{C}_{\text {error }}$ values showing an underestimation of predicted values (Figure 4).

\section{DISCUSSION}

Lipids greatly influenced the carbon isotopic composition of soft tissues of tropical tuna as evidenced by the significant increase in $\delta^{13} \mathrm{C}$ after lipid extraction, especially in fat tissues such as liver, gonads and red muscle (Table 2). As lipid composition varies among tissues, species and 305 individuals (related to life cycle, i.e. reproduction, sex, age, migration, starvation and/or to environmental factors), lipid normalization techniques are required for interpreting carbon isotopic composition. The lipid extraction method using dichloromethane only, as proposed by Bodin et $a l .{ }^{[24]}$, had a negligible effect on $\delta^{15} \mathrm{~N}$ values (increase of $0.1 \%$ in mean) across tissues and tuna species (Table 2). This modification is under the IRMS precision $(0.15 \%)$ confirming that distinct analyses of $\delta^{13} \mathrm{C}$ and $\delta^{15} \mathrm{~N}$ values are not required for tropical tuna tissues with this chemical extraction. Moreover, the low total lipid content found in white muscle (less than $3 \% \mathrm{dw}$, Table 2) and its composition (proteins and polar lipids, Figure 2) revealed that lipid removal prior to SIA is 
not essential for this tissue. For the fattest tissues (i.e., liver and possibly gonads), however, a longer ASE extraction process using maybe more solvent compared to the method of Bodin et al. ${ }^{[24]}$ might

315 be necessary to remove properly most of lipid compounds.

The liver of topical tuna was characterized by an high $\mathrm{C}: \mathrm{N}$ ratio $(\mathrm{C}: \mathrm{N}=5.7 \pm 0.3)$ even after two ASE extraction cycles. A similar result was previously observed in sea bass liver $(\mathrm{C}: \mathrm{N}$ ratio $=$ $5.6^{[30]}$ ) and could reflect the peculiar C:N signature of proteins in tuna liver. But this high ratio could also relate to highly polar lipids that were not totally extracted with the method of Bodin et $320 a{ }^{[24]}$. Indeed, by using a medium polar solvent (dichloromethane with dipole moment of $1.6 \mathrm{D}$ ), this method removes neutral and medium polar lipid compounds but not the most polar ones (e.g. some phospholipids or lipoproteins) in order to avoid any unwanted effect on $\delta^{15} \mathrm{~N}$ value ${ }^{[24]}$. The additional biochemical analyses performed in the present study revealed the high quantity of proteins and phospholipids in the liver of tropical tuna (Figure 2), and therefore strengthened the

325 second hypothesis that the observed high $\mathrm{C}: \mathrm{N}$ ratio in the ASE-extracted liver reflected the signature of proteins and remaining highly polar lipids.

\section{Lipid correction models}

To overcome a tedious, time-consuming, and costly chemical extraction process, we investigated

330 different mathematical models that deal with lipid contents and predict lipid-corrected isotopic values using SIA of the bulk tissue and different covariates. We analyzed several tissues of three tropical tuna species and estimated specific parameters with our dataset. The confidence of the tissue-specific models was thoroughly assessed using a cross validation procedure that tested their predictive ability. Models using published parameters' estimates from other species systematically

335 failed to predict lipid-corrected $\delta^{13} \mathrm{C}$ values. Such approaches are definitively not suited for trophic studies using SIA. Linear and non-linear models (i.e., equations of Post et $a l^{[32]}$ and McConnaughey and McRoy ${ }^{[25]}$, respectively) provided accurate $\delta^{13} \mathrm{C}$ predictions when parameters were estimated for each tissue and from our dataset. The mass balance equation of Fry ${ }^{[27]}$ gave reliable predictions for white muscle only, which is the leanest tissue (i.e., lipid content $<10 \% \mathrm{dw}$ ).

340 But the mass balance equation led to systematic biased predictions for red muscle, liver and gonads: predicted values were underestimated and a larger mismatch was observed for gonads (mean $\Delta \delta^{13} \mathrm{C}_{\text {error }}=-0.28$ ) and liver (mean $\Delta \delta^{13} \mathrm{C}_{\text {error }}=-0.18$ ) than for red muscle (mean $\Delta \delta^{13} \mathrm{C}_{\text {error }}=-0.05$ ) (Figure 4). For red muscle, liver and gonads, discrepancies between lipid-free and corrected values of a given model could be great. The maximum $\Delta \delta^{13} \mathrm{C}_{\text {error }}$ ranged from $1.2 \%$ in red muscle with

345 [eq2] and [eq3] to more than 1.6\% in liver with [eq1] and 1.6\% in gonads with [eq3]. Despite these discrepancies, [eq1] and [eq2] provided accurate predictions in all tissue and in about $90 \%$ of the time. Therefore they can be used for correcting bulk $\delta^{13} \mathrm{C}$ values in trophic studies according to a 
close range of lipid content that we measured in our tuna tissues. But we do not recommend [eq3] that gave systematic biaised predictions for red muscle, liver and gonads, despite errors within an

350 acceptable range for ecological interpretations. We suspected that this result relied on the correct estimation of $\mathrm{C}: \mathrm{N}_{\text {lipid-free }}$ as previously observed ${ }^{[30]}$. Indeed discrepancies between lipid-free and corrected values increased with the C: $\mathrm{N}_{\text {lipid-free }}$ variability: $54 \%$ of good prediction for red muscles with a $\mathrm{C}: \mathrm{N}_{\text {lipid-free }}$ variability around $3.6 \%$, which went down to $10-1720 \%$ in gonads and liver with a C: $\mathrm{N}_{\text {lipid-free }}$ close to $9 \%$.

355 However all models did not required the same level of information. The equations of McConnaughey and $\operatorname{McRoy}^{[25]}$ (i.e. [eq1]) and the mass balance approach of Fry ${ }^{[27]}$ (i.e. [eq3]) required empirical information in addition to the estimation of parameters from a part of the dataset: the lipid content $L$, which was sample dependant for [eq1], and the $\mathrm{C}: \mathrm{N}$ of pure proteins that varied among tissue and needed lipid-free samples for [eq3]. Moreover adjusted parameters were also 360 tissue-specific. For instance $D$, which was estimated from our dataset, varied among tissue in [eq1] mainly and in [eq3] to a lesser extent, and between [eq1] and [eq3] (Table 5), suggesting that $D$ is not constant but could vary according to tissue composition. The highest $D$ values were estimated in liver for both [eq1] and [eq2], but no clear trend was observed between $D$ estimates and the mean total lipid nor between $D$ estimates and lipid classes (TAG and PL) of each tissue. Further

365 biochemical analyzes involving for instance the dynamics of fatty acids (see below) are needed to understand the processes of lipid-protein discrimination. The estimation process might weaken here the basic assumptions of biochemical composition used in the mass balance approach. Finally [eq2] was easier to implement as this model did not require lipid content and thus we recommend its use for tropical tuna according to the range of lipid content we measured in the tissues under study.

370 Therefore correction models used to mathematically normalize $\delta^{13} \mathrm{C}$ values for lipid contents require a proportion of the original dataset for estimating parameters specific to tissue, while chemical extraction of lipids necessitates the process of all samples. Here we combined data of the three tuna species despite the fact that some differences were highlighted by statistical tests. We then increased the amount of data and improved the precision of the parameters' estimation process.

375 Species- or sex-specific models (results not shown) did not make better the predictions and led to very close parameters' values confirming that tissue is the most important factor to consider in lipid correction models, as already noted by Logan et al. ${ }^{[35]}$. However extrapolation to other species or extra tissues should not be performed without estimating specific parameters.

As already mentioned, white muscle of BET, SKJ and YFT did not require lipid removal and any correction model would provide a suitable correction for trophic investigations, regarding the small difference between bulk and lipid-free $\delta{ }^{13} \mathrm{C}$ values (around $0.1 \%$ ). A mean error of more or less 
$0.1 \%$ in $\delta^{13} \mathrm{C}$ values would not alter ecological interpretation and is in the range of the measurement error of the device as well. However, when multi-tissue SIA are carried out using fatter tissues or when comparative studies aim at investigating the role and position of different species in marine

385 food webs, samples have to be processed in the same way, i.e. chemical lipid extraction or normalization using specific mathematical models. Although expensive, chemical extraction has the advantage to gain additional valuable information such as the total lipid content of tissues, which is commonly used as a proxy of nutritional and/or energetic condition of fish ${ }^{[55-57]}$.

\section{Tissue metabolism and isotopic composition}

Strong differences were observed in $\delta^{13} \mathrm{C}$ and $\delta^{15} \mathrm{~N}$ values among the tissues of the three tuna species. Tissues showed indeed a large variability in lipid and protein contents, and metabolism affects most likely isotopic composition. Hereafter the objective is not to interpret our findings in a trophic context but to discuss physiological factors that could influence our isotopic results. Among

395 the two types of tuna muscles, red muscle accounts for less than around $10 \%$ of the total body weight, depending on the fish species and size ${ }^{[58]}$. Indeed, due to increased endothermic efficiency with age, the proportion of red muscle tends to decrease ${ }^{[58]}$. Red and white muscles have different functions in tuna. White muscle is activated during fast and short-duration swimming bursts fueled by catabolized glycogen and anaerobic metabolism. In contrast red muscle is activated during

400 routine swimming and is based on aerobic lipids catabolism (i.e. fatty acid degradation for energy production $)^{[59,60]}$. Indeed, storage lipids are rather found in red muscle compared to white muscle (Figure 2). Catabolism preferentially uses and excretes light isotopes. In the case of red and white muscles, catabolized substrates have different isotopic signatures: lipids are depleted in $\delta^{13} \mathrm{C}$ relatively to glycogen ${ }^{[18]}$. This could explain the lower $\delta^{13} \mathrm{C}$ values observed in the red muscle 405 compared to white muscle in this study.

However, lipid metabolism could also have specific preferences that will influence the isotopic composition. Sidell et al. ${ }^{[61]}$ noted that some monounsatured fatty acids are preferentially used for energy metabolism in the muscle of an Antarctic fish. As fatty acids could have different $\delta^{13} \mathrm{C}$ values according to their origins ${ }^{[62]}$, the resulting carbon pool could be differentially affected. In 410 addition, Koussoroplis et al. ${ }^{[63]}$ showed that fatty acids from structural (PL) or storage (TAG) lipids have different $\delta^{13} \mathrm{C}$ values in the grey mullet, thus proportion and use of each lipid class could influence isotopic composition of each tissue. Similarly, McMahon et al. ${ }^{[64]}$ showed that fish muscle $\delta^{13} \mathrm{C}$ values is greatly influenced by the amino acids available in the diet and by the metabolic ways activated to synthesize the missing ones.

415 Nitrogen isotopic composition depends on the amino acid metabolism through deamination and transamination processes ${ }^{[65]}$. Tissues with high protein turnover (i.e., ratio between protein 
degradation and synthesis) excrete lighter nitrogen leading to a ${ }^{15} \mathrm{~N}$-enrichment. In this way, higher $\delta^{15} \mathrm{~N}$ values are expected in liver which is characterized by faster turnover than muscles in fish (e.g. ${ }^{[9,12,66]}$ ). However, in tropical tuna, the lower $\delta^{15} \mathrm{~N}$ values observed in liver compared to muscle $^{[46, \text { this study] }}$ suggest that other factors are at play such as tissue growth (higher proteins synthesis) or tissue specific metabolism. Indeed liver contains high levels of proteins and plays a central function in amino acid and fatty acid metabolism and their exchange with other tissues ${ }^{[67]}$. Its isotopic composition should be greatly influenced by compounds brought by diet or their synthesis and degradation for the organism requirement. Lower $\delta^{15} \mathrm{~N}$ values could also suggest low 425 reuse of proteins on site, thus protein are rapidly transferred in other tissues. Details in essential and non-essential amino acid and fatty acid proportions would improve our conclusions in terms of compound distribution from the liver to tissues.

On the other hand, in the red muscle of teleost fish, glutamine, a non-essential amino acid, is catabolised by mitochondria "on site" (not in liver like in mammals) in addition to fatty acid 430 metabolism ${ }^{[68,69]}$. This characteristic of red muscle could explain its high $\delta^{15} \mathrm{~N}$ values although it contains lower proportion of proteins compared to other tissues (Figure 2). The differences of total protein contents between the two types of muscle may be linked with their myofibrillar protein levels: while muscle cells typically contain a high quantity of these compounds, red muscle is characterized by a lower fiber diameter and thus a lower myofibrillar protein level to ensure the 435 efficiency of its large number of mitochondria ${ }^{[60,70]}$. Starvation may also cause a tissue ${ }^{15} \mathrm{~N}$ enrichment but these situations seems unlikely in tuna who have high energetic requirements: experiments on SKJ and YFT have actually disclosed a limited ability to survive starvation ${ }^{[71]}$.

Gonads were the only tissue that showed sex difference in isotopic composition: $\mathrm{C}: \mathrm{N}$ ratio increased with maturity (i.e, GSI) in females. However the decrease in male gonads is constrained by C:N 440 ratio in non mature males (i.e., GSI < 1.5, Figure 3). The variation in proximal composition supports this pattern: proteins and reserve lipids were more abundant in female gonads of BET and SKJ (Figure 2) and this is probably linked to the different requirements between ovary and testis during maturation process. In females, liver products vitellogenin (Vtg), a large glycolipoprotein intended to energy storage in eggs. A greater Vtg accumulation in bluefin tuna Thunnus thynnus

445 was suggested to be correlated with diet quality and especially with diet dominated by squid, which are rich in protein and phospholipids ${ }^{[72]}$. Thus diet quality could influence the ovary isotopic composition. Further studies suggest also that oleic acid, a specific fatty acid, is preferentially used in females for the yolk supply in fish ${ }^{[73,74]}$. High levels of PolyUnsaturated Fatty Acids (PUFA) in eggs are also correlated with better quality and fecundity in many fish species ${ }^{[75,76]}$. By this way, maternal investment could also affect ovary isotopic composition. But sperm is rich in ATP and glucose, which are essential for its mobility. The nucleotide concentration (ATP-ADP-AMP) could 
therefore be used as an indicator of sperm quality ${ }^{[7]}$. Many differences of compounds during maturation could thereby explain differences in isotopic composition among sexes.

Moreover, differences in gonad $\delta^{13} \mathrm{C}$ values were also observed among tuna species. Indeed different reproductive strategies are observed for the three species ${ }^{[78-82]}$. The reproductive investment of SKJ females mobilizes more energy storage by means of lipid than males, which is common in fish. However more analyses on energy allocation strategy of these species are required to better understand the isotopic routing, and thus the isotopic composition of ovary and testis. Lastly our results showed that the reproductive investment of the three species did not truly depend on the energy storage in the other tissues, as variation in isotopic or in biochemical compositions with GSI were observed in gonads only. The understanding of isotopic routing is an important step required to improve multi-tissue isotopic studies. Indeed the multi-tissue approach promises interesting results on tropical tuna. For example, Graham et al. ${ }^{[46]}$ detected a diet shift at $45-50 \mathrm{~cm}$ FL in Pacific YFT by comparing isotopic results in muscle and liver on the one hand and stomach contents on the other hand.

\section{Conclusion}

Mathematical corrections of lipid content can be applied on bulk $\delta^{13} \mathrm{C}$ values of white and red muscles, liver and gonads of yellowfin, bigeye and skipjack tuna. However parameters have to be estimated from a proportion of the original data for which chemical extraction is required and isotopic values of bulk and lipid-free tissues are measured. On the one hand, we recommend using the linear model of Post $e t a l .{ }^{[32]}$ for tuna tissues with a similar range of lipid content $(0.3-45 \%)$, as it was the most simple to implement with our dataset. On the other hand the mass balance approach was not suitable for correcting bulk $\delta^{13} \mathrm{C}$ values of red muscle, liver and gonads of tuna. Models 475 using published parameters' estimates from extra species cannot be used to account for lipid correction in trophic studies using SIA. Multi-tissue stable isotope analyses help to disentangle the complex relations between diet, physiological condition (growth, reproduction, starvation...) and the tissue-specific metabolism. The proportions of essential and non-essential fatty acids and amino acids metabolized in fish tissues shape isotopic composition, and compound-specific isotopic analyses would improve our understanding of tissue metabolism.

\section{Acknowledgements}

We are grateful all the SFA technicians lab and in particular Maria Cedras, Greg Burke and Rodney Melanie for their help throughout the tuna sampling. We wish also to thank the contributions of the 
the IRD Tuna Observatory (UMR MARBEC, Seychelles). We thank also Hervé Guillou and his team (UMR TOXALIM, Toulouse, France) for their help in the preparation of the samples of lipid class and protein analyses. Finally we thank three anonymous referees for their remarks and suggestions that greatly improved the manuscript. This work is a contribution to projects EMOTION, CANAL and ALECAP, respectively founded by ANR, MW Brands IOT Ltd. and France Filière Pêche.

\section{REFERENCES}

[1] R. H. Michener, D. M. Schell, Stable Isotope Ratios as Tracers in Marine Food Webs, in 495 Stable Isotopes in Ecology and Environmental Science, (Eds: R. Michener, K. Lajtha). Blackwell Publishing Ltd, Oxford, UK, 1994, pp. 138-157.

[2] T. Miller. Tissue-specific response of $\delta^{15} \mathrm{~N}$ in adult Pacific herring (Clupea pallasi) following an isotopic shift in diet. Environ. Biol. Fishes 2000, 76, 177.

[3] T. D. Jardine, D. L. MacLatchy, W. L. Fairchild, R. A. Cunjak, S. B. Brown. Rapid Carbon Turnover During Growth of Atlantic Salmon (Salmo salar) Smolts in Sea Water, and Evidence for Reduced Food Consumption by Growth-Stunts. Hydrobiologia 2004, 527, 63.

[4] G. D. Sherwood, R. M. Rideout, S. B. Fudge, G. A. Rose. Influence of diet on growth, condition and reproductive capacity in Newfoundland and Labrador cod (Gadus morhua): Insights from stable carbon isotopes $\left(\delta^{13} \mathrm{C}\right)$. Deep Sea Res. Part II Top. Stud. Oceanogr. 2007, $54,2794$.

[5] C. N. Trueman, R. A. R. McGill, P. H. Guyard. The effect of growth rate on tissue-diet isotopic spacing in rapidly growing animals. An experimental study with Atlantic salmon (Salmo salar). Rapid Commun. Mass Spectrom. 2005, 19, 3239.

[6] L. Lee Cruz, R. A. R. McGill, S. J. Goodman, K. C. Hamer. Stable isotope ratios of a tropical marine predator: confounding effects of nutritional status during growth. Mar. Biol. 2012, 159, 873.

[7] N. E. Hussey, M. A. MacNeil, B. C. McMeans, J. A. Olin, S. F. J. Dudley, G. Cliff, S. P. Wintner, S. T. Fennessy, A. T. Fisk. Rescaling the trophic structure of marine food webs. Ecol. Lett. 2014, 17, 239.

[8] J. K. Pinnegar, N. V. C. Polunin. Differential fractionation of $\delta^{13} \mathrm{C}$ and $\delta^{15} \mathrm{~N}$ among fish tissues: implications for the study of trophic interactions. Funct. Ecol. 1999, 13, 225.

[9] M. MacNeil, G. B. Skomal, A. T. Fisk. Stable isotopes from multiple tissues reveal diet switching in sharks. Mar. Ecol. Prog. Ser. 2005, 302, 199.

[10] J. Logan, H. Haas, L. Deegan, E. Gaines. Turnover rates of nitrogen stable isotopes in the salt marsh mummichog, Fundulus heteroclitus, following a laboratory diet switch. Oecologia 2006, 147, 391.

[11] J. Guelinckx, J. Maes, P. Van Den Driessche, B. Geysen, F. Dehairs, F. Ollevier. Changes in $\delta^{13} \mathrm{C}$ and $\delta^{15} \mathrm{~N}$ in different tissues of juvenile sand goby Pomatoschistus minutus: a laboratory diet-switch experiment. Mar. Ecol. Prog. Ser. 2007, 341, 205.

[12] A. Buchheister, R. J. Latour. Turnover and fractionation of carbon and nitrogen stable isotopes in tissues of a migratory coastal predator, summer flounder (Paralichthys dentatus). Can. J. Fish. Aquat. Sci. 2010, 67, 445.

[13] D. J. Madigan, S. Y. Litvin, B. N. Popp, A. B. Carlisle, C. J. Farwell, B. A. Block. Tissue Turnover Rates and Isotopic Trophic Discrimination Factors in the Endothermic Teleost, Pacific Bluefin Tuna (Thunnus orientalis). PLoS ONE 2012, 7, e49220.

[14] C. M. Kurle, G. A. Worthy. Stable nitrogen and carbon isotope ratios in multiple tissues of the northern fur seal Callorhinus ursinus: implications for dietary and migratory reconstructions. 
Mar. Ecol. Prog. Ser. 2002, 236, 289.

[15] T. D. Jardine, M. A. Gray, S. M. McWilliam, R. A. Cunjak. Stable Isotope Variability in Tissues of Temperate Stream Fishes. Trans. Am. Fish. Soc. 2005, 134, 1103.

[16] C. Martinez del Rio, N. Wolf, S. A. Carleton, L. Z. Gannes. Isotopic ecology ten years after a call for more laboratory experiments. Biol. Rev. 2009, 84, 91.

[17] L. J. Kelly, C. M. Del Rio. The fate of carbon in growing fish: an experimental study of isotopic routing. Physiol. Biochem. Zool. 2010, 83, 473.

[18] M. DeNiro, S. Epstein. Mechanism of carbon isotope fractionation associated with lipid synthesis. Science 1977, 197, 261.

[19] B. A. Murry, J. M. Farrell, M. A. Teece, P. M. Smyntek. Effect of lipid extraction on the interpretation of fish community trophic relationships determined by stable carbon and nitrogen isotopes. Can. J. Fish. Aquat. Sci. 2006, 63, 2167.

[20] M. A. Sotiropoulos, W. M. Tonn, L. I. Wassenaar. Effects of lipid extraction on stable carbon and nitrogen isotope analyses of fish tissues: potential consequences for food web studies. Ecol. Freshw. Fish 2004, 13, 155.

[21] T. Ingram, B. Matthews, C. Harrod, T. Stephens, J. Grey, R. Markel, A. Mazumder. Lipid extraction has little effect on the $\delta^{15} \mathrm{~N}$ of aquatic consumers. Limnol Ocean. Methods 2007, 5, 338.

[22] C. Schlechtriem, U. Focken, K. Becker. Effect of different lipid extraction methods on $\delta^{13} \mathrm{C}$ of lipid and lipid-free fractions of fish and different fish feeds. Isotopes Environ. Health Stud. 2003, 39, 135.

[23] J. M. Logan, M. E. Lutcavage. A comparison of carbon and nitrogen stable isotope ratios of fish tissues following lipid extractions with non-polar and traditional chloroform/methanol solvent systems. Rapid Commun. Mass Spectrom. 2008, 22, 1081.

[24] N. Bodin, H. Budzinski, K. Le Ménach, N. Tapie. ASE extraction method for simultaneous carbon and nitrogen stable isotope analysis in soft tissues of aquatic organisms. Anal. Chim. Acta 2009, 643, 54.

[25] T. McConnaughey, C. P. McRoy. Food-web structure and the fractionation of carbon isotopes in the Bering Sea. Mar. Biol. 1979, 53, 257.

[26] M. F. Leggett. Food-web dynamics of Lake Ontario as determined by carbon and nitrogen stable isotope analysis. University of Waterloo, 1998.

[27] B. Fry. Stable isotopic indicators of habitat use by Mississippi River fish. J. North Am. Benthol. Soc. 2002, 21, 676.

[28] B. Fry, D. M. Baltz, M. C. Benfield, J. W. Fleeger, A. Gace, H. L. Haas, Z. J. QuiñonesRivera. Stable isotope indicators of movement and residency for brown shrimp (Farfantepenaeus aztecus) in coastal Louisiana marshscapes. Estuaries 2003, $26,82$.

[29] M. Kiljunen, J. Grey, T. Sinisalo, C. Harrod, H. Immonen, R. I. Jones. A revised model for lipid-normalizing $\delta^{13} \mathrm{C}$ values from aquatic organisms, with implications for isotope mixing models: Revised lipid-normalization model for C isotope analysis. J. Appl. Ecol. 2006, 43, 1213.

[30] C. J. Sweeting, N. V. C. Polunin, S. Jennings. Effects of chemical lipid extraction and arithmetic lipid correction on stable isotope ratios of fish tissues. Rapid Commun. Mass Spectrom. 2006, 20, 595.

[31] N. Bodin, F. Le Loc'h, C. Hily. Effect of lipid removal on carbon and nitrogen stable isotope ratios in crustacean tissues. J. Exp. Mar. Biol. Ecol. 2007, 341, 168.

[32] D. M. Post, C. A. Layman, D. A. Arrington, G. Takimoto, J. Quattrochi, C. G. Montaña. Getting to the fat of the matter: models, methods and assumptions for dealing with lipids in stable isotope analyses. Oecologia 2007, 152, 179.

[33] P. M. Smyntek, M. A. Teece, K. L. Schulz, S. J. Thackeray. A standard protocol for stable isotope analysis of zooplankton in aquatic food web research using mass balance correction models. Limnol. Oceanogr. 2007, 52, 2135.

[34] J. Kojadinovic, F. Ménard, P. Bustamante, R. Cosson, M. Le Corre. Trophic ecology of 
marine birds and pelagic fishes from Reunion Island as determined by stable isotope analysis. Mar. Ecol. Prog. Ser. 2008, 361, 239.

[35] J. M. Logan, T. D. Jardine, T. J. Miller, S. E. Bunn, R. A. Cunjak, M. E. Lutcavage. Lipid corrections in carbon and nitrogen stable isotope analyses: comparison of chemical extraction and modelling methods. J. Anim. Ecol. 2008, 77, 838.

[36] K. Mintenbeck, T. Brey, U. Jacob, R. Knust, U. Struck. How to account for the lipid effect on carbon stable-isotope ratio $\left(\delta^{13} \mathrm{C}\right)$ : sample treatment effects and model bias. J. Fish Biol. 2008, 72,815 .

[37] J. L. Doucette, B. Wissel, C. M. Somers. Effects of lipid extraction and lipid normalization on stable carbon and nitrogen isotope ratios in double-crested cormorants: implications for food web studies. Waterbirds 2010, 33, 273.

[38] S. Oppel, R. N. Federer, D. M. O’Brien, A. N. Powell, T. E. Hollmén. Effects of lipid extraction on stable isotope ratios in avian egg yolk: is arithmetic correction a reliable alternative? The Auk 2010, 127, 72.

[39] J. C. Hoffman, T. T. Sutton. Lipid correction for carbon stable isotope analysis of deep-sea fishes. Deep Sea Res. Part Oceanogr. Res. Pap. 2010, 57, 956.

[40] J. Syväranta, M. Rautio. Zooplankton, lipids and stable isotopes: importance of seasonal, latitudinal, and taxonomic differences. Can. J. Fish. Aquat. Sci. 2010, 67, 1721.

[41] D. Ehrich, A. Tarroux, J. Stien, N. Lecomte, S. Killengreen, D. Berteaux, N. G. Yoccoz. Stable isotope analysis: modelling lipid normalization for muscle and eggs from arctic mammals and birds: Lipid normalization for stable isotope analysis. Methods Ecol. Evol. 2011, 2, 66 .

[42] J. C. P. Reum. Lipid correction model of carbon stable isotopes for a cosmopolitan predator, spiny dogfish Squalus acanthias. J. Fish Biol. 2011, 79, 2060.

[43] C. Ryan, B. McHugh, C. N. Trueman, C. Harrod, S. D. Berrow, I. O'Connor. Accounting for the effects of lipids in stable isotope $\left(\delta^{13} \mathrm{C}\right.$ and $\delta^{15} \mathrm{~N}$ values) analysis of skin and blubber of balaenopterid whales: Lipid extraction in stable isotope analysis of whale skin and blubber. Rapid Commun. Mass Spectrom. 2012, 26, 2745.

[44] K. H. Elliott, M. Davis, J. E. Elliott. Equations for Lipid Normalization of Carbon Stable Isotope Ratios in Aquatic Bird Eggs. PLoS ONE 2014, 9, e83597.

[45] R. M. Wilson, J. P. Chanton, B. C. Balmer, D. P. Nowacek. An evaluation of lipid extraction techniques for interpretation of carbon and nitrogen isotope values in bottlenose dolphin (Tursiops truncatus) skin tissue. Mar. Mammal Sci. 2014, 30, 85.

[46] B. S. Graham, D. Grubbs, K. Holland, B. N. Popp. A rapid ontogenetic shift in the diet of juvenile yellowfin tuna from Hawaii. Mar. Biol. 2006, 150, 647.

[47] F. Ménard, A. Lorrain, M. Potier, F. Marsac. Isotopic evidence of distinct feeding ecologies and movement patterns in two migratory predators (yellowfin tuna and swordfish) of the western Indian Ocean. Mar. Biol. 2007, 153, 141.

[48] A. T. Revill, J. W. Young, M. Lansdell. Stable isotopic evidence for trophic groupings and bio-regionalization of predators and their prey in oceanic waters off eastern Australia. Mar. Biol. 2009, 156, 1241.

[49] R. J. Olson, B. N. Popp, B. S. Graham, G. A. López-Ibarra, F. Galván-Magaña, C. E. LennertCody, N. Bocanegra-Castillo, N. J. Wallsgrove, E. Gier, V. Alatorre-Ramírez, L. T. Ballance, B. Fry. Food-web inferences of stable isotope spatial patterns in copepods and yellowfin tuna in the pelagic eastern Pacific Ocean. Prog. Oceanogr. 2010, 86, 124.

[50] F. Ménard, C. Labrune, Y-J. Shin, A-S. Asine, F-X. Bard. Opportunistic predation in tuna: a size-based approach. Mar. Ecol. Prog. Ser. 2006, 323, 223.

[51] C. Bessey, M. A. Vanderklift. Drying method has no substantial effect on $\delta^{15} \mathrm{~N}$ or $\delta^{13} \mathrm{C}$ values of muscle tissue from teleost fishes: Effect of drying method on $\delta^{15} \mathrm{~N}$ and $\delta^{13} \mathrm{C}$ values of fish muscle tissue. Rapid Commun. Mass Spectrom. 2014, 28, 265.

[52] C. C. Parrish, Determination of total lipid, lipid classes, and fatty acids in aquatic samples, in Lipids in Freshwater Ecosystems, (Eds: M.T. Arts, B.C. Wainmann). Springer, 1999, pp. 4 
20.

[53] N. Bodin, V. Lucas, P. Dewals, M. Adeline, J. Esparon, E. Chassot. Effect of brine immersion freezing on the determination of ecological tracers in fish. Eur. Food Res. Technol. 2014, 238, 1057.

[54] R Core Team. R: A Language and Environment for Statistical Computing. R Foundation For Statistical Computing, Vienna, Austria, 2013.

[55] S. M. Adams, Ecological Role of Lipids in the Health and Success of Fish Populations, in Lipids in Freshwater Ecosystems (Eds: M.T. Arts, B.C. Wainman). Springer New York, New York, NY, 1999, pp. 132-160.

[56] L. P. Weber, P. S. Higgins, R. I. Carlson, D. M. Janz. Development and validation of methods for measuring multiple biochemical indices of condition in juvenile fishes. J. Fish Biol. 2003, 63, 637.

[57] H. Pethybridge, N. Bodin, E. J. Arsenault-Pernet, J. H. Bourdeix, B. Brisset, J. L. Bigot, D. Roos, M. Peter. Temporal and inter-specific variations in forage fish feeding conditions in the NW Mediterranean: lipid content and fatty acid compositional changes. Mar. Ecol. Prog. Ser. 2014, 512, 39.

[58] J. B. Graham, F. J. Koehrn, K. A. Dickson. Distribution and relative proportions of red muscle in scombrid fishes: consequences of body size and relationships to locomotion and endothermy. Can. J. Zool. 1983, 61, 2087.

[59] P. G. Arthur, T. G. West, R. W. Brill, P. M. Schulte, P. W. Hochachka. Recovery metabolism of skipjack tuna (Katsuwonus pelamis) white muscle: rapid and parallel changes in lactate and phosphocreatine after exercise. Can. J. Zool. 1992, 70, 1230.

[60] K. A. Dickson. Locomotor muscle of high-performance fishes: What do comparisons of tunas with ectothermic sister taxa reveal? Comp. Biochem. Physiol. A Physiol. 1996, 113, 39.

[61] B. D. Sidell, E. L. Crockett, W. R. Driedzic. Antarctic fish tissues preferentially catabolize monoenoic fatty acids. J. Exp. Zool. 1995, 271, 73.

[62] S. M. Budge, M. J. Wooller, A. M. Springer, S. J. Iverson, C. P. McRoy, G. J. Divoky. Tracing carbon flow in an arctic marine food web using fatty acid-stable isotope analysis. Oecologia 2008, 157, 117.

[63] A. Koussoroplis, A. Bec, M. Perga, E. Koutrakis, C. Desvilettes, G. Bourdier. Nutritional importance of minor dietary sources for leaping grey mullet Liza saliens (Mugilidae) during settlement: insights from fatty acid $\delta^{13} \mathrm{C}$ analysis. Mar. Ecol. Prog. Ser. 2010, 404, 207.

[64] K. W. McMahon, M. L. Fogel, T. S. Elsdon, S. R. Thorrold. Carbon isotope fractionation of amino acids in fish muscle reflects biosynthesis and isotopic routing from dietary protein: Carbon isotope fractionation of fish muscle amino acids. J. Anim. Ecol. 2010, 79, 1132.

[65] S. A. Macko, M. L. F. Estep, M. H. Engel, P. E. Hare. Kinetic fractionation of stable nitrogen isotopes during amino acid transamination. Geochim. Cosmochim. Acta 1986, 50, 2143.

[66] K. W. Suzuki, A. Kasai, K. Nakayama, M. Tanaka. Differential isotopic enrichment and halflife among tissues in Japanese temperate bass (Lateolabrax japonicus) juveniles: implications for analyzing migration. Can. J. Fish. Aquat. Sci. 2005, 62, 671.

[67] J. Brusle, G. G. Anadon. The structure and function of fish liver. Fish Morphol. 1996, 77.

[68] M. E. Chamberlin, H. C. Glemet, J. S. Ballantyne. Glutamine metabolism in a holostean (Amia calva) and teleost fish (Salvelinus namaycush). Am. J. Physiol.-Regul. Integr. Comp. Physiol. 1991, 260, R159.

[69] J. S. Ballantyne. Mitochondria: aerobic and anaerobic design-lessons from molluscs and fishes. Comp. Biochem. Physiol. B Biochem. Mol. Biol. 2004, 139, 461.

[70] J. C. George, E. D. Stevens. Fine structure and metabolic adaptation of red and white muscles in tuna. Environ. Biol. Fishes 1978, 3, 185.

[71] C. H. Boggs, J. F. Kitchell. Tuna metabolic rates estimated from energy losses during starvation. Physiol. Zool. 1991, 502.

[72] C. Pousis, C. De Giorgi, C. C. Mylonas, C. R. Bridges, R. Zupa, R. Vassallo-Agius, F. de la Gándara, C. Dileo, G. De Metrio, A. Corriero. Comparative study of liver vitellogenin gene 
expression and oocyte yolk accumulation in wild and captive Atlantic bluefin tuna (Thunnus thynnus L.). Anim. Reprod. Sci. 2011, 123, 98.

[73] J. S. Ballantyne, F. Mercure, M. F. Gerrits, G. Van Der Kraak, S. McKinley, D. W. Martens, S. G. Hinch, R. E. Diewert. Plasma nonesterified fatty acid profiles in male and female sockeye salmon, (Oncorhynchus nerka), during the spawning migration. Can. J. Fish. Aquat. Sci. 1996, 53, 1418.

[74] X. Huang, Y. Yin, Z. Shi, W. Li, H. Zhou, W. Lv. Lipid content and fatty acid composition in wild-caught silver pomfret (Pampus argenteus) broodstocks: Effects on gonad development. Aquaculture 2010, 310, 192.

[75] C. Yanes-Roca, N. Rhody, M. Nystrom, K. L. Main. Effects of fatty acid composition and spawning season patterns on egg quality and larval survival in common snook (Centropomus undecimalis). Aquaculture 2009, 287, 335.

[76] M. M. Bachan, I. A. Fleming, E. A. Trippel. Maternal allocation of lipid classes and fatty acids with seasonal egg production in Atlantic cod (Gadus morhua) of wild origin. Mar. Biol. 2012, 159, 2281.

[77] L. Zilli, R. Schiavone, V. Zonno, C. Storelli, S. Vilella. Adenosine triphosphate concentration and $\beta$-d-glucuronidase activity as indicators of sea bass semen quality. Biol. Reprod. 2004, 70, 1679.

[78] M. Grande, H. Murua, I. Zudaire, M. Korta. Oocyte development and fecundity type of the skipjack, Katsuwonus pelamis, in the Western Indian Ocean. J. Sea Res. 2012, 73, 117.

[79] I. Zudaire, H. Murua, M. Grande, M. Korta, H. Arrizabalaga, J. J. Areso, A. Delgado-Molina. Fecundity regulation strategy of the yellowfin tuna (Thunnus albacares) in the Western Indian Ocean. Fish. Res. 2013, 138, 80

[80] M. Grande, H. Murua, I. Zudaire, N. Goñi, N. Bodin. Reproductive timing and reproductive capacity of the Skipjack Tuna (Katsuwonus pelamis) in the western Indian Ocean. Fisheries Research 2014, 156, 14.

[81] I. Zudaire, H. Murua, M. Grande, N. Bodin. Reproductive potential of yellowfin tuna (Thunnus albacares) in the western Indian Ocean. Fishery Bulletin 2013, 111, 252.

[82] I. Zudaire, H. Murua, M. Grande, F. Pernet, N. Bodin. Accumulation and mobilization of lipids in relation to reproduction of yellowfin tuna (Thunnus albacares) in the Western Indian Ocean. Fisheries Research 2014, 160, 50. 


\section{Figure caption}

Figure 1. Relationship between bulk $\mathrm{C}: \mathrm{N}$ ratio and total lipid content (\% dw) for each tissue. A curvilinear model was significant in white muscle only. Coefficients of determination $\left(\mathrm{R}^{2}\right)$ are given.

505 Figure 2. Lipid and protein composition (in \% ww) of the white muscle, red muscle, liver and gonads of the three tropical tuna species. Reserve lipids refer to TriAcylGlycerol (TAG) and structural lipids to Phospholipids (PL). Gonad F = female gonads; Gonad M = male gonads.

Figure 3. Linear regression models between lipid-free $\mathrm{C}: \mathrm{N}$ ratio and the Gonado-Somatic Index (GSI) in gonads of males and females of the three tropical tuna species.

510 Figure 4. Distributions of the $\Delta \delta^{13} \mathrm{C}_{\text {error }}$, i.e. the differences between the lipid-corrected and observed lipid-free $\delta^{13} \mathrm{C}$ values. Lipid-corrected values were predicted from the three lipidnormalization models using a cross validation procedure that was repeated 500 times. $\Delta \delta^{13} \mathrm{C}_{\text {error }}=$ $\delta^{13} \mathrm{C}_{\text {corrected }}-\delta^{13} \mathrm{C}_{\text {lipid-free }}$

\section{Table caption}

Table 1. Non-exhaustive inventory of lipid-correction models from the literature and developed for marine organisms. Many studies compared different models using their data and are cited in the corresponding model type.

Table 2. Mean values ( \pm standard deviation) of total lipid content $(\% \mathrm{dw})$, isotopic data $\left(\delta^{13} \mathrm{C}, \delta^{15} \mathrm{~N}\right)$ and C:N ratios for bulk and lipid-free samples in the gonads $(\mathrm{G})$, liver $(\mathrm{L})$, red muscle $(\mathrm{R})$ and white muscle (W) of tropical tuna (YFT=yellowfin; BET=bigeye; SKJ=skipjack) sampled in the Western Indian Ocean.

Table 3. Results of the two chemical extractions performed successively on 40 samples: mean values ( \pm standard deviation) of $\delta^{13} \mathrm{C}$ and $\delta^{15} \mathrm{~N}$ values, and $\mathrm{C}: \mathrm{N}$ ratio of bulk samples and after

525 chemical extractions. Letters indicate significant differences $(p<0.05)$ based on Wilcoxon's test: $a$ $=$ different from bulk, $b=$ different from first extraction.

Table 4. Diagnostic statistics of the linear regression models with $\Delta \delta^{15} \mathrm{~N}$ and $\Delta \delta^{13} \mathrm{C}$ as dependant variables, and lipid content, tissue, species and sex as explanatory variables. $\Delta \delta^{15} \mathrm{~N}=\delta^{15} \mathrm{~N}_{\text {lipid-free }}$ $\delta^{15} \mathrm{~N}_{\text {bulk }}$ and $\Delta \delta^{13} \mathrm{C}=\delta^{13} \mathrm{C}_{\text {lipid-free }}-\delta^{13} \mathrm{C}_{\text {bulk }}$, i.e. the differences between the isotopic values of bulk 530 and lipid-free samples.

Table 5. Estimated parameter values ( \pm standard deviation) from our dataset of the three correction models that predict lipid-corrected $\delta^{13} \mathrm{C}$ values (see text). 
1

Table 6. Assessment of the prediction of the three models [eq1], [eq2], [eq3] using a cross validation procedure that was repeated 500 times, and in the two parameters' configuration: based 535 on our dataset (Table 4) and based on published studies (see text). Paired Wilcoxon's tests were carried out for each model and at each trial to compare predicted $\left(\delta^{13} \mathrm{C}_{\text {corr }}\right)$ and observed $\left(\delta^{13} \mathrm{C}_{\text {lipid- }}\right.$ free) values. Good predictions are expressed in $\%$ of acceptable $p$-values (i.e., $\%$ of $p$-values $>0.05$ ) for the 500 iterations. Mean and maximum values of $\Delta \delta^{13} \mathrm{C}_{\text {error }}=\delta^{13} \mathrm{C}_{\text {corrected }}-\delta^{13} \mathrm{C}_{\text {lipid-free }}$ are specified. 


\begin{tabular}{|c|c|c|c|c|c|}
\hline & Taxon & Tissue & $\mathrm{N}$ & $\begin{array}{l}\text { Bulk C:N } \\
\text { (min-max) }\end{array}$ & Ref. \\
\hline \multirow{7}{*}{$\left.I+\frac{3.9}{1+287 / L}\right)_{\text {sured or calculated as }}$} & Bering sea organisms (plankton to mammals) & Various & 75 & $3.2-9.2$ & 25 \\
\hline & 14 fishes / 5 invertebrates & Muscle / Whole & 227 & 2.9-9.4 & 29 \\
\hline & Zooplankton spp. & Whole & 120 & $4.8-17.8$ & 33 \\
\hline & 2 seabirds & Muscle / Liver / Feathers & 94 & $3.2-7.1$ & 34 \\
\hline & 2 antarctic fishes & Muscle & 20 & $3.6-7.1$ & 36 \\
\hline & 16 fishes / 10 invertebrates & Muscle / Liver / Gonad / Whole & 431 & $2.5-12.5$ & 35 \\
\hline & 2 cormorants & Muscle / Liver & 137 & 4.4-5.5 & 37 \\
\hline \multirow{6}{*}{$\begin{array}{l}\text { nation } \\
\text { taset }\end{array}$} & 2 seabirds & Eggs & 40 & $13.2-17.1$ & 38 \\
\hline & Zooplankton spp. & Whole & 103 & $3.8-19.3$ & 40 \\
\hline & Spiny dogfish & Muscle / Liver & 40 & $3.4-20$ & 42 \\
\hline & 3 whales & Skin / Blubber & 120 & $4.5-22.2$ & 43 \\
\hline & 16 fishes / 10 invertebrates & Muscle / Liver / Gonad / Whole & 431 & $2.5-12.5$ & 35 \\
\hline & 30 deepfishes & Muscle & 87 & $4.1-8.5$ & 39 \\
\hline \multirow{7}{*}{$\begin{array}{l}\text { crimination } \\
\text { ed to dataset }\end{array}$} & Mammals / birds & Muscle / Eggs & 229 & $3-20.2$ & 41 \\
\hline & 3 whales & Skin / Blubber & 120 & $4.5-22.2$ & 43 \\
\hline & Zooplankton & Whole & - & $3.2-10$ & 26 \\
\hline & 16 aquatic animals & Muscle & 28 & $3.0-6.9$ & 32 \\
\hline & Spider crab & Muscle / Gonad / Hepatopancreas & 46 & $2.7-51$ & 31 \\
\hline & 2 seabirds & Muscle / Liver / Feathers & 94 & $3.2-7.1$ & 34 \\
\hline & 2 antarctic fishes & Muscle & 20 & $3.6-7.1$ & 36 \\
\hline \multirow[t]{4}{*}{ djusted to dataset } & 2 cormorants & Muscle/ Liver & 137 & $1.1-5.5$ & 37 \\
\hline & Zooplankton spp. & Whole & 103 & $3.8-19.3$ & 40 \\
\hline & 3 whales & Skin / Blubber & 120 & $4.5-22.2$ & 43 \\
\hline & Dolphin & Skin & 35 & $3.1-4.5$ & 45 \\
\hline \multirow{6}{*}{$\begin{array}{l}\text { bulk }) \\
\text { adjusted to dataset }\end{array}$} & 16 fishes / 10 invertebrates & Muscle / Liver / Gonad / Whole & 431 & $2.5-12.5$ & 35 \\
\hline & Zooplankton spp. & Whole & 103 & $3.8-19.3$ & 40 \\
\hline & Mammals / birds & Muscle / Eggs & 229 & $3-20.2$ & 41 \\
\hline & Spiny dogfish & Muscle / Liver & 40 & $3.4-20$ & 42 \\
\hline & 3 whales & Skin / Blubber & 120 & $4.5-22.2$ & 43 \\
\hline & 8 aquatics birds & Eggs & 175 & $4-17$ & 44 \\
\hline \multirow{5}{*}{ crimination } & 7 freshwater fishes & Muscle & 116 & $3.2-8.2$ & 27 \\
\hline & 16 fishes / 10 invertebrates & Muscle / Liver / Gonad / Whole & 431 & $2.5-12.5$ & 35 \\
\hline & Mammals / birds & Muscle / Eggs & 229 & $3-20.2$ & 41 \\
\hline & Spiny dogfish & Muscle / Liver & 40 & $3.4-20$ & 42 \\
\hline & 3 whales & Skin / Blubber & 120 & $4.5-22.2$ & 43 \\
\hline \multirow{4}{*}{ 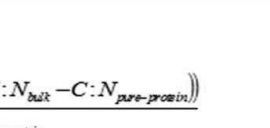 } & Shrimp & Hepatopancreas & 138 & - & 28 \\
\hline & Seabass & Muscle /Liver & 1256 & $4-19$ & 30 \\
\hline & Zooplankton spp. & Whole & 120 & $4.8-17.8$ & 33 \\
\hline & 2 antarctic fishes & Muscle & 20 & $3.63-7.14$ & 36 \\
\hline mosin & 2 cormorants & Muscle / Liver & 137 & $4.4-5.5$ & 37 \\
\hline \multirow[t]{3}{*}{ crimination } & 30 deep fishes & Muscle & 87 & $4.1-8.5$ & 39 \\
\hline & Zooplankton spp. & Whole & 103 & $3.8-19.3$ & 40 \\
\hline & Dolphin & Skin & 35 & $3.1-4.5$ & 45 \\
\hline
\end{tabular}




\begin{tabular}{ccccccccc}
\hline & & \multirow{3}{*}{ Tissue } & $\mathrm{n}$ & $\begin{array}{c}\text { Lipid content } \\
(\%) \mathrm{dw}\end{array}$ & \multicolumn{4}{c}{$\mathrm{BULK}$} \\
\cline { 4 - 9 } & & & $\delta^{13} \mathrm{C}(\%)$ & $\delta^{15} \mathrm{~N}(\%)$ & $\mathrm{C}: \mathrm{N}$ & $\delta^{13} \mathrm{C}(\%)$ & $\delta^{15} \mathrm{~N}(\%)$ & $\mathrm{C}: \mathrm{N}$ \\
\hline $\mathrm{W}$ & 39 & $2.8 \pm 1.8$ & $-17.3 \pm 0.4$ & $12.5 \pm 0.8$ & $3.16 \pm 0.09$ & $-17.1 \pm 0.3$ & $12.7 \pm 0.8$ & $3.09 \pm 0.04$ \\
$\mathrm{R}$ & 39 & $11.4 \pm 5.2$ & $-18.7 \pm 0.5$ & $13.3 \pm 0.8$ & $4.10 \pm 0.33$ & $-17.8 \pm 0.4$ & $13.4 \pm 0.8$ & $3.53 \pm 0.13$ \\
$\mathrm{~L}$ & 39 & $15.5 \pm 7.6$ & $-19.0 \pm 0.7$ & $11.4 \pm 0.8$ & $5.00 \pm 1.00$ & $-17.5 \pm 0.4$ & $11.5 \pm 0.8$ & $3.92 \pm 0.41$ \\
$\mathrm{G}$ & 21 & $10.4 \pm 6.6$ & $-17.8 \pm 1.0$ & $11.1 \pm 0.6$ & $3.52 \pm 0.61$ & $-16.8 \pm 0.5$ & $11.2 \pm 0.6$ & $3.05 \pm 0.31$ \\
$\mathrm{~W}$ & 42 & $2.1 \pm 0.5$ & $-17.1 \pm 0.3$ & $11.1 \pm 0.9$ & $3.11 \pm 0.05$ & $-17.0 \pm 0.3$ & $11.1 \pm 0.8$ & $3.06 \pm 0.04$ \\
$\mathrm{R}$ & 41 & $9.9 \pm 2.9$ & $-18.5 \pm 0.5$ & $12.3 \pm 0.9$ & $3.96 \pm 0.19$ & $-17.7 \pm 0.4$ & $12.3 \pm 0.9$ & $3.51 \pm 0.14$ \\
$\mathrm{~L}$ & 42 & $15.1 \pm 5.5$ & $-18.9 \pm 0.6$ & $10.4 \pm 1.0$ & $4.68 \pm 0.76$ & $-17.6 \pm 0.4$ & $10.5 \pm 1.0$ & $3.74 \pm 0.37$ \\
$\mathrm{G}$ & 31 & $11.9 \pm 2.5$ & $-18.4 \pm 0.6$ & $10.4 \pm 1.1$ & $3.65 \pm 0.43$ & $-17.1 \pm 0.6$ & $10.5 \pm 1.1$ & $3.03 \pm 0.31$ \\
$\mathrm{~W}$ & 48 & $2.3 \pm 1.1$ & $-16.9 \pm 0.4$ & $11.7 \pm 1.0$ & $3.15 \pm 0.16$ & $-16.8 \pm 0.4$ & $11.9 \pm 0.9$ & $3.06 \pm 0.03$ \\
$\mathrm{R}$ & 48 & $11.7 \pm 3.5$ & $-18.4 \pm 0.5$ & $12.8 \pm 1.0$ & $4.11 \pm 0.33$ & $-17.5 \pm 0.4$ & $12.9 \pm 1.0$ & $3.53 \pm 0.13$ \\
$\mathrm{~L}$ & 48 & $19.6 \pm 11.2$ & $-19.1 \pm 1.1$ & $10.9 \pm 0.9$ & $5.10 \pm 1.31$ & $-17.3 \pm 0.5$ & $11.0 \pm 1.0$ & $3.68 \pm 0.28$ \\
$\mathrm{G}$ & 30 & $12.5 \pm 7.6$ & $-18.0 \pm 1.1$ & $10.7 \pm 0.7$ & $3.67 \pm 0.95$ & $-16.6 \pm 0.6$ & $10.8 \pm 0.7$ & $2.98 \pm 0.23$ \\
\hline
\end{tabular}

1st lipid-extraction 2nd lipid-extraction

\begin{tabular}{cc}
18.6 & 2.1 \\
$-17.4 \pm 0.5^{\mathrm{a}}$ & $-17.4 \pm 0.4^{\mathrm{ab}}$ \\
$11.3 \pm 0.6$ & $11.3 \pm 0.7^{\mathrm{a}}$ \\
$4.25 \pm 0.30^{\mathrm{a}}$ & $5.74 \pm 0.32^{\mathrm{ab}}$ \\
\hline
\end{tabular}

http://mc.manuscriptcentral.com/rcm 


\begin{tabular}{lcccccc}
\hline & $\Delta \delta^{15} \mathrm{~N}$ & & & \multicolumn{3}{c}{$\Delta \delta^{13} \mathrm{C}$} \\
\cline { 1 - 4 } \cline { 5 - 7 } quares & $\mathrm{F}$ value & $\operatorname{Pr}(>\mathrm{F})$ & & Mean Squares & $\mathrm{F}$ value & $\operatorname{Pr}(>\mathrm{F})$ \\
\hline 203 & 2.69 & $\mathrm{NS}$ & & 12.036 & 3170.06 & $\mathrm{p}<0.001$ \\
2388 & 3.79 & $\mathrm{p}<0.05$ & & 0.184 & 48.39 & $\mathrm{p}<0.001$ \\
234 & 2.41 & $\mathrm{NS}$ & & 0.008 & 2.09 & $\mathrm{NS}$ \\
423 & 0.71 & $\mathrm{NS}$ & & 0.027 & 7.15 & $\mathrm{p}<0.01$ \\
\hline
\end{tabular}

http://mc.manuscriptcentral.com/rcm 
Table 5.

\begin{tabular}{|c|c|c|c|c|c|}
\hline \multirow[b]{2}{*}{ Tissue } & \multicolumn{2}{|c|}{$\begin{array}{l}\text { McConnaughey \& } \\
\text { McRoy }^{[25]}[\text { eq1] }\end{array}$} & \multicolumn{2}{|c|}{ Post et al. ${ }^{[32]}$ [eq2] } & \multirow{2}{*}{$\begin{array}{l}\begin{array}{l}\text { Logan et } \\
\text { al. }^{[35]}[\mathrm{eq} 3]\end{array} \\
\boldsymbol{D}\end{array}$} \\
\hline & $D$ & I & $a$ & $b$ & \\
\hline W & $6.4 \pm 0.9$ & $-0.012 \pm 0.004$ & $1.97 \pm 0.13$ & $-6.05 \pm 0.42$ & $6.6 \pm 0.38$ \\
\hline $\mathrm{R}$ & $6.2 \pm 0.4$ & $0.001 \pm 0.009$ & $1.01 \pm 0.07$ & $-3.22 \pm 0.26$ & $6.6 \pm 0.09$ \\
\hline $\mathrm{L}$ & $8.1 \pm 0.3$ & $-0.018 \pm 0.007$ & $0.76 \pm 0.02$ & $-2.18 \pm 0.12$ & $6.9 \pm 0.1$ \\
\hline G & $7.4 \pm 0.4$ & $0.028 \pm 0.008$ & $0.59 \pm 0.08$ & $-0.817 \pm 0.29$ & $6.8 \pm 0.16$ \\
\hline
\end{tabular}

Table 6.

\begin{tabular}{|c|c|c|c|c|c|c|c|c|c|}
\hline & \multicolumn{4}{|c|}{ Adjuted parameters } & \multicolumn{4}{|c|}{ Literature parameters } \\
\hline & & $\mathbf{W}$ & $\mathbf{R}$ & $\mathbf{L}$ & $\mathbf{G}$ & $\mathbf{W}$ & $\mathbf{R}$ & $\mathbf{L}$ & $\mathbf{G}$ \\
\hline \multirow{3}{*}{$\begin{array}{l}\text { McConnaughey \& } \\
\text { McRoy }^{[25]} \text { [eq1] }\end{array}$} & Good predictions $(\%)$ & 88 & 89 & 86 & 89 & 0 & 0 & 0 & 0 \\
\hline & Mean $\Delta \delta^{13} \mathrm{C}_{\mathrm{error}}(\% \mathrm{o})$ & $-0.001 \pm 0.035$ & $-0.001 \pm 0.046$ & $-0.001 \pm 0.068$ & $0.004 \pm 0.055$ & $0.3 \pm 0.03$ & $-1.3 \pm 0.03$ & $-1.6 \pm 0.05$ & $-1.7 \pm 0.04$ \\
\hline & $\operatorname{Max} \Delta \delta^{13} \mathrm{C}_{\text {error }}(\% 0)$ & 0.6 & 0.9 & 1.6 & 1 & 1.9 & 2 & 2.8 & 2.2 \\
\hline \multirow{3}{*}{ Post et al. ${ }^{[32]}$ [eq2] } & Good predictions (\%) & 88 & 91 & 90 & 89 & 0 & 0 & 92 & 0 \\
\hline & Mean $\Delta \delta^{13} \mathrm{C}_{\text {error }}(\%)$ & $-0.002 \pm 0.029$ & $0.0 \pm 0.045$ & $-0.005 \pm 0.076$ & $0.004 \pm 0.091$ & $-0.4 \pm 0.02$ & $-0.2 \pm 0.03$ & $0.0 \pm 0.06$ & $-1.1 \pm 0.07$ \\
\hline & $\operatorname{Max} \Delta \delta{ }^{13} \mathrm{C}_{\text {error }}(\% 0)$ & 0.5 & 1.2 & 1.3 & 1 & 0.8 & 1 & 1.5 & 1.9 \\
\hline \multirow{3}{*}{ Fry $^{[27]}[$ eq3] } & Good predictions (\%) & 87 & 54 & 16.9 & 10.2 & 0 & 0 & 0 & 0 \\
\hline & Mean $\Delta \delta^{13} \mathrm{C}_{\text {error }}(\% 0)$ & $-0.002 \pm 0.028$ & $-0.047 \pm 0.029$ & $-0.184 \pm 0.04$ & $-0.278 \pm 0.036$ & $-0.1 \pm 0.03$ & $-0.9 \pm 0.05$ & $-1.9 \pm 0.16$ & $-1.4 \pm 0.09$ \\
\hline & $\operatorname{Max} \Delta \delta^{13} \mathrm{C}_{\text {error }}(\% 0)$ & 0.5 & 1.2 & 1.4 & 1.6 & 0.67 & 1.8 & 5.2 & 3.2 \\
\hline
\end{tabular}

http://mc.manuscriptcentral.com/rcm 

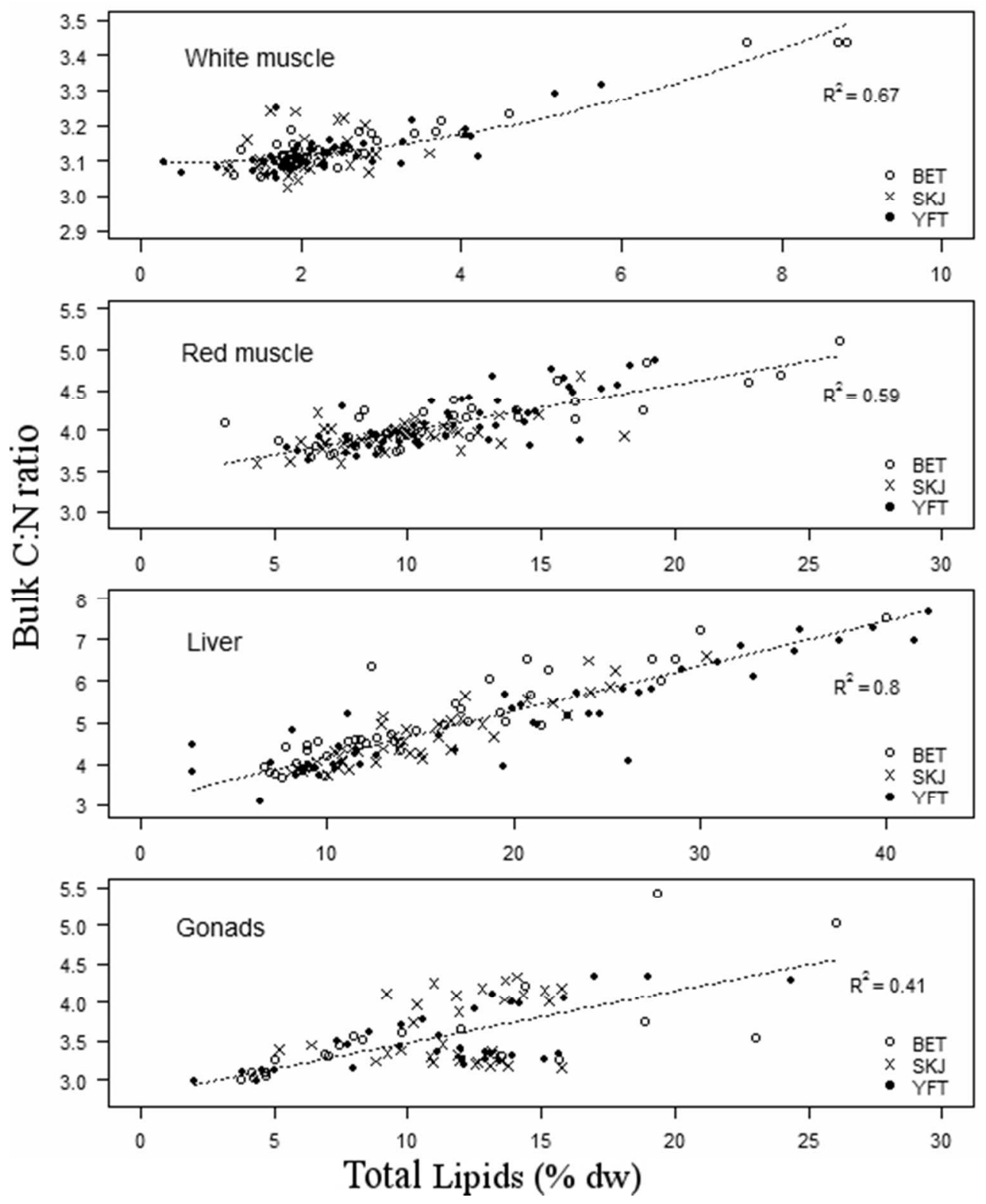

Figure 1. Relationship between bulk C: $N$ ratio and total lipid content ( $\% d w)$ for each tissue. A curvilinear model was significant in white muscle only. Coefficients of determination $(R</ 2>)$ are given. $195 \times 235 \mathrm{~mm}(72 \times 72 \mathrm{DPI})$

http://mc.manuscriptcentral.com/rcm 

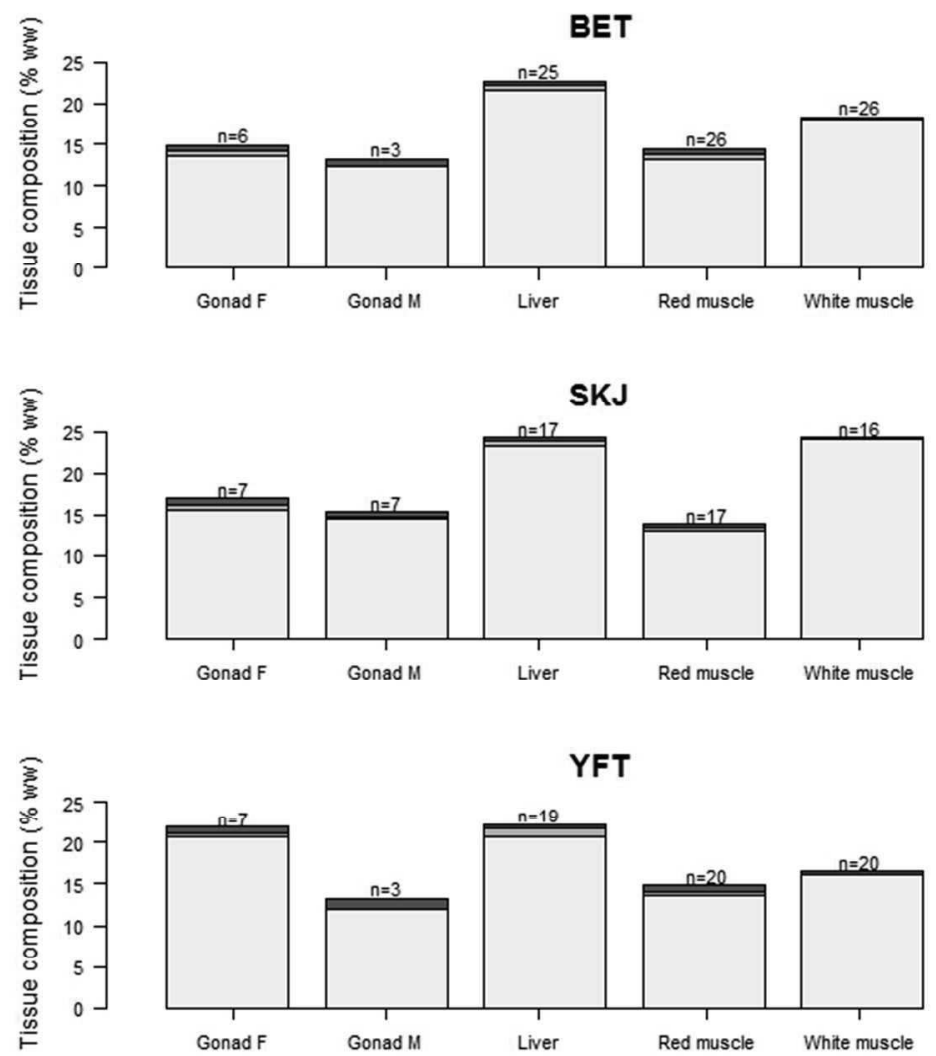

$\square$ Proteins

$\square$ Storage lipids

$\square$ Structural lipids

Figure 2. Lipid and protein composition (in \% ww) of the white muscle, red muscle, liver and gonads of the three tropical tuna species. Reserve lipids refer to TriAcylGlycerol (TAG) and structural lipids to Phospholipids (PL). Gonad F = female gonads; Gonad M = male gonads. 


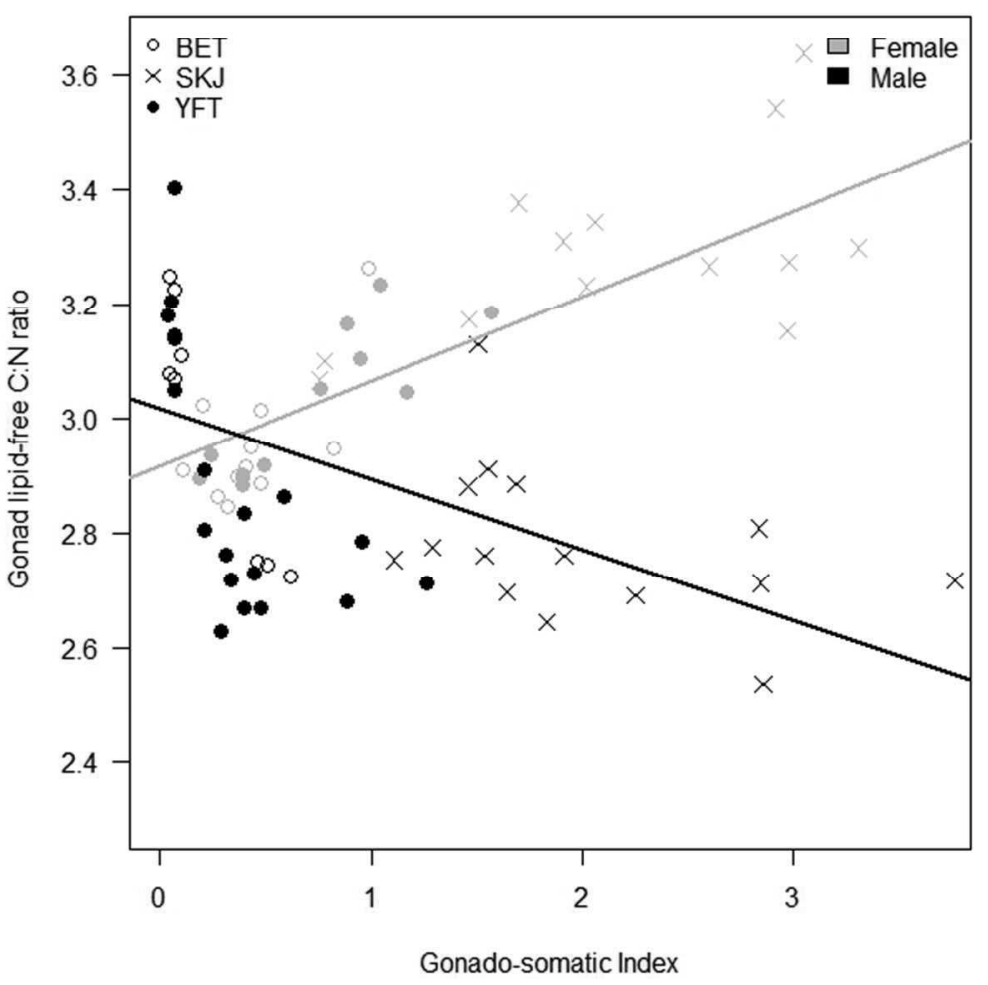

Figure 3. Linear regression models between lipid-free C:N ratio and the Gonado-Somatic Index (GSI) in gonads of males and females of the three tropical tuna species. 


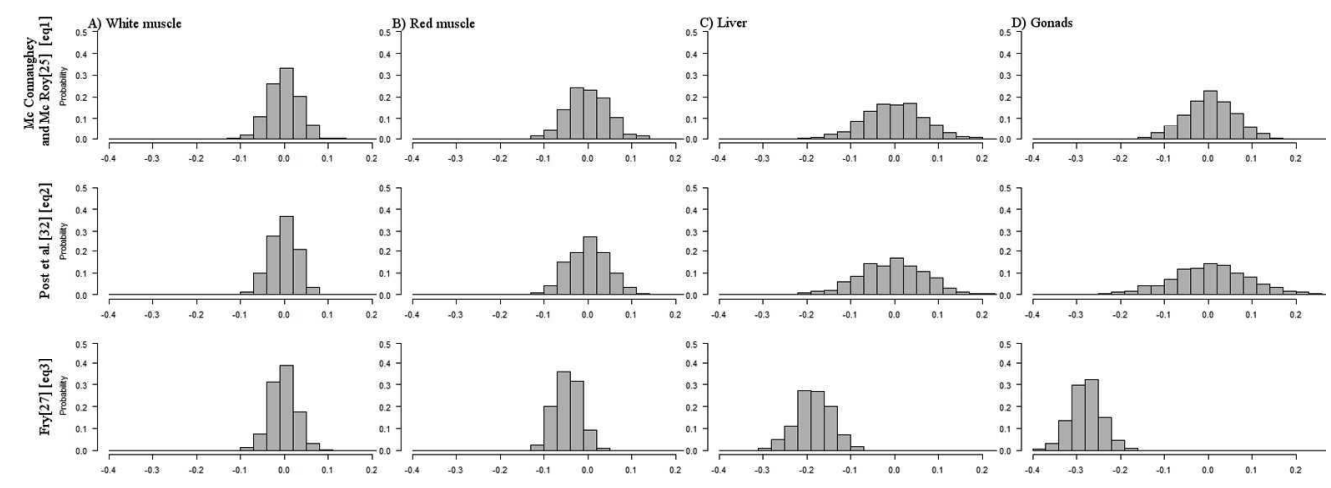

Figure 4. Distributions of the $\Delta \delta 13$ Cerror, i.e. the differences between the lipid-corrected and observed lipidfree $\delta 13 C$ values. Lipid-corrected values were predicted from the three lipid-normalization models using a cross validation procedure that was repeated 500 times. $\Delta \delta 13$ Cerror $=\delta 13$ Ccorrected $-\delta 13$ Clipid-free $592 \times 210 \mathrm{~mm}(72 \times 72$ DPI $)$ 